\section{International Journal of Thermophysics}

(D648B)

発行所: Plenum Puhlishing Co. (New York)

編集者: Ared Cezairliyan (National Bureau of Standards, USA)

使用言語：英語

刊行周期：季刊

創刊年月：1980年 3 月

購読料：66ドル／年（米国内は58ドル）

Purdue 大学にある CINDAS (Center for Information and Numerical Data Analysis and Synthesis) 飞和いて，熱物性関係の新しい 雑誌の必要性に関する 3 年間にわたる国際的調査 分析の結果発刊するに至ったもので，熱物性デー タの生産者およびユーザの双方に役立つことを目 的とした科学的, 工学的熱物性分野を広くカバー する国際誌。

団体，液体，気体状態の物質について，広範囲 の温度, 圧力領域の熱的性質およびそれに関連し た性質の理論的，実験的研究を揭載する。すなお ち，1)熱容量, エンタルピー, 蒸気圧, 表面張 力, 相変化, PVT などの熱力学的性質叔よび熱 量測定, 2) 熱伝導, 電気伝導, 蓺拡散, 粘性など の輸送的性質, 3) 発光, 吸収, 反射, 光学定数な ぞの熱放射的性質，4)熱物性測定に関連した新規 な実験法牱よび測定装置，5)熱物性分野のトピッ クスのレビュー，6)参照物質, 評価, 測定法の標 準化，7)熱物性データの収集, 評価法,8)工学的 応用 etc を含む。100 200語程度の報告的抄録 および 4 〜 語のキーワードつき。創刊号は CODATA の熱物性タスクグループによる「固 体の熱物性に関する科学技術情報の 1 次文献の発
表についての規準」を含めて件 9 揭載。

\section{Cretaceous Research}

(D994 B)

発行所: Academic Press (London)

編集者: E. G. Kauffman (Smithsonian

Institution, USA), R. A. Reyment

(Uppsala University, Sweden)

使用言語：英語汃仏語

刊行周期：季刊

創刊年月：1980年

購読料 : 88.5 ドル /年

白业紀に関する研究は以前では層位学か古生物 学に関係するものに限られていたが, 今では地球 物理学, 石油地質学, たい積学, テクトニクス, 海洋学とその分野が多様化してきている。これら の研究により, 現在の地球の性質を解明する上で 白亜紀のもつ特別な意味が明瞭になりつつある。 国際地層対比計画の “白亜紀中期事件” プロジェ クトで研究された報告集と関連して問題が生じ た。これに参加した研究者の中から白亜紀問題を 取り扱う雑誌創刊の声が高まり，本誌が刊行され ることになった。

本誌は地域地質, 層位学, 構造地質学, 古生物 学などの古典的な研究分野に加え, 白亜紀岩類の 地球化学と岩石学, 海洋の進化, 海洋底テクトニ クス, 深海研究, 古生物地理学, 古生態学, 鈗床 学などを扱ったあらゆる観点からのジュラ紀特よ び第三紀との境界を含む白覀紀研究に対する討論 の場を用意する目的で刊行された。

揭載記事は, 原著論文, 短 報, アブストラク ト，書評で構成。1 号は92ページで, 論文 4 , 短 報 2 ，アブストラクト，書評を収録。 